$\frac{\text { DE }}{\mathrm{G}} \stackrel{\substack{\text { DE GRUYTER } \\ \text { OPEN }}}{ }$

DOI: 10.2478/topling-2014-0011

\title{
The phonological basis of Latin case patterns ${ }^{1}$
}

\author{
Joseph Embley Emonds \\ Palacký University, Czech Republic
}

\begin{abstract}
This study focuses on accounting for allomorphy in Latin case/number inflection. It attributes essentially all of it to the influence of adjacent features of standard segmental phonology on morphemes expressing case assignment. Indeed, other languages lead linguists to expect that allomorphy at a stem-suffix border can depend on any feature of a final vowel: \pm Low, \pm High, \pm Round, \pm Back, \pm Consonantal or \pm Syllabic. Empirically, it turns out that no two Latin stem-final vowels induce identical allomorphy in case/number suffixes, nor the same allomorphy as final consonants. Moreover, some (not much) phonologically conditioned allomorphy is phonetically opaque.

These two factors have led traditional scholarship to conclude that each stem-final segment should define a separate classification of noun suffixation or "declension". As there are basically six types of final segment ( $a, o, u, i, e$ and consonants), each then gives rise to a different declension (stems with final $i$ are often put in some other group or considered irregular), thus creating five (or six) declensions. Tradition then goes on to analyse stem-final vowels not as part of stems but as some kind of separate morphemes called "thematic vowels" (with no role in either syntax or phonology).

This essay argues rather that an unflinching modern and formal approach to inflectional allomorphy, exactly analogous to using phonology to reduce regular English plurals to a single lexical form, succeeds in sweeping away the sandcastle of Latin declensions and better captures the actual descriptive generalizations that account for Latin case inflection.
\end{abstract}

\section{Keywords}

Ablative, case marking, case syncretism, dative, declension, fusion, Latin case, lexical convention, neuter gender, optional segment.

\footnotetext{
${ }^{1}$ I gratefully thank Heather Goad, Carlos Piera, Phillip Spaelti, Ludmila Veselovská, and audiences at talks at Kyoto University and University College London for discussions about many aspects of the analyses presented here. Their comments have much improved the essay's accuracy and helped remove several errors. I also thank two anonymous reviewers for Topics in Linguistics for their helpful comments and suggestions.

An earlier version of this essay has appeared as Emonds (2009). That essay did not succeed in finding an adequate analysis of the important Latin nominative singular alternation - $s / \varnothing$, while this one has. Though most of the empirical data here was in the earlier version, the organization and presentation of the theoretical ideas in the first half of this essay are, I believe, much improved in the direction of comprehensibility; certain nearly irrelevant passages on syntactic Case theory have been removed. This essay also revises and more systematically makes use of an important theoretical proposal called the Lexical Parenthesis Convention. A number of other basic notions here appeared earlier in Spaelti (2004) and/or Emonds and Spaelti (2005).
} 
Introduction

During the two thousand years preceding modern linguistics, Latin grammar was the most intensely studied area of linguistic enquiry, and serious investigations of it continue to this day (Spaelti, 2004; Baldi and Cuzzolin, 2009; Cser, to appear). Yet the widely accepted categories and organization of this knowledge, i.e. Latin "declensions" and "conjugations", have remained resolutely immune to the influence of generative or any other modern methodology.

The traditional organization of Latin declensions (of nouns and adjectives) and conjugations (of verbs) exercises a strange hold, rarely acknowledged, on linguistics even today. However little individual grammarians and phonologists know about the language, they are somehow subject, I conjecture, to the following beliefs:

(i) Latin grammar is quite complicated, relatively speaking, yet these complications exhibit real and quite specific regularities.

(ii) These notable regularities, to some extent shared by Classical Greek and Sanskrit, are in a domain called Morphology.

(iii) The categories of this Morphology, namely grammatical gender, declensions, conjugations, and at least some cases, are independent of both phonology and syntactic categories directly related to grammatical meaning.

(iv) These very real and close to languageparticular regularities of Latin demonstrate that there are generalizations in natural language that fall outside of syntax and phonology, at least as we currently understand them.

Summarizing, today's linguists largely share the following unconscious legacy of Latin grammatical tradition:

(1) Autonomous Morphology. Complex language-particular generalizations of a morphological nature fall outside of currently familiar principles and rules based only on phonology and syntax.

Some current Latinists take issue with this perspective, such as Spaelti (2004) and especially Cser. The latter explicitly disavows aspects of (1): "As a consequence, we believe that denoting stem-final segments as e.g. thematic vowels (as in Aronoff 1994) or any other morphological or quasi-morphological entity is of little use" (Cser, to appear: Section 1).

In accord with this approach, limited here to examining the case patterns of Latin nouns (traditionally organized into its "declensions"), I would like to slowly unravel some of the considerations that have led to the beliefs (i)-(iv), which were of course conscious among those who formulated traditional descriptions of Latin. As we investigate various aspects of Latin case patterns and some concepts related to them, we will see that their morphological specificity tends to melt away and that the really significant linguistic generalizations of Latin are revealed to conform rather to familiar principles and practices of modern linguistic analysis. That is, I will proceed in a direction that seems to indicate that the system of Latin nominal case leads not to adherence to (1), but to its opposite.

\section{Latin noun stems}

A linguist unacquainted with Latin may at first fail to recognize anything controversial in the following simple and plausible statements about Latin case inflections. However, we will soon see that several implications of the following are indeed far from generally accepted.

Latin noun stems, like Latin words in general, can end in one or (less often) two consonants or any one of its five distinct vowels (putting aside vowel length). Case and number features are apparently fused as single suffixes on these stems. ${ }^{2}$ Here are typical examples:

(2) labor-'work', flūmin- 'river', lēg- 'law', urb- 'city', turri- 'tower', manu- 'hand', rē-

2 The fusion of Case and Number features in single unanalysable inflections is the standard accepted view and is taken to show that Latin has a special marked "fusional" property. Like so many other aspects of Latin morphology, this fusion has served as an unspoken model for postulating fused feature sets for a range of inflections across other languages. However, Latin number and case inflections may well be linear ("agglutinative") sequences of a separate plural morpheme usually spelled out as lengthening of an adjacent vowel, followed by Case features, properly speaking. Since such a linear analysis would conform to Baker's (1985) "Mirror Principle", it would move Latin even further away from being "special" and toward its being a typical human language. This paper will not pursue this, since one descendent of Latin (Italian) has undeniably fused gender and number features into a single segment: $-o$ masc. sing., $-i$ masc. pl., $-a$ fem. sing., $-e$ fem. plur. So whether this fusion was already a characteristic of Latin is not a very crucial issue. 
'thing', stēlla- 'star', puero- 'boy', equo'horse'

Latin case inflections, like the ablative singular suffix, usually consist of or begin with vocalic segments. This leads to significant phonological interaction between stem-final and suffix-initial vowels, giving rise to allomorphy on "both sides of the border" (at ends of stems and beginnings of suffixes). This extensive but purely phonological allomorphy has confused essentially all analyses of Latin case inflection, as observed a century ago by Sapir (1921: Ch. 6).

To discuss a concrete and not entirely simple example of such allomorphy, we need to provisionally accept both the traditional case names and the forms of the fused case/number inflections. In these terms, we can observe a range of examples in which stem-final back vowels delete before suffix-initial unrounded vowels. ${ }^{3}$ The symbol \# stands for the border between stems and case/number inflections.

(3) Stem-final Vowel Truncation:

[ +Syllabic, +Back] $\rightarrow \varnothing /$--- \# $\left[_{\text {CASE }}[\right.$-Round] ... ]

\begin{tabular}{|c|c|c|c|}
\hline $\begin{array}{c}\text { nauta } \\
- \text { ìs }\end{array}$ & $\rightarrow$ nautīs & 'by sailors' & $\begin{array}{c}\text { (ablative } \\
\text { plural) }\end{array}$ \\
\hline $\begin{array}{c}\text { equo } \\
-\bar{i}\end{array}$ & $\rightarrow$ equī & 'slaves' & $\begin{array}{c}\text { (nominative } \\
\text { plural) }\end{array}$ \\
\hline $\begin{array}{c}\text { bello } \\
-\bar{i}\end{array}$ & $\rightarrow$ belli & 'of war' & $\begin{array}{l}\text { (genitive } \\
\text { singular) }\end{array}$ \\
\hline $\begin{array}{l}\text { portu } \\
- \text { ibus }\end{array}$ & $\overrightarrow{\text { portibus }^{4}}$ & $\begin{array}{c}\text { '(from) } \\
\text { harbours' }\end{array}$ & $\begin{array}{l}\text { (ablative } \\
\text { plural) }\end{array}$ \\
\hline $\begin{array}{c}\text { fîlio - } \\
\bar{i}\end{array}$ & $\rightarrow$ fili & 'son!' & (vocative) \\
\hline $\begin{array}{l}\text { Bruto } \\
-\mathrm{e}\end{array}$ & $\rightarrow$ Brute & ‘Brutus!’ & (vocative) \\
\hline $\begin{array}{l}\text { bello } \\
-\mathrm{a}\end{array}$ & $\rightarrow$ bella & 'wars' & $\begin{array}{c}\text { (accusative } \\
\text { plural) }\end{array}$ \\
\hline
\end{tabular}

Such stem vowel truncation before suffixes is by no means particular to Latin; for

3 Some segment-specific phonetics can circumvent the application of (3). For instance, in later Latin stem-final $a$ combines with suffixal $i$ to yield a mid-vowel $\bar{e}$, spelled ae: nauta- $\bar{I} \rightarrow$ nautae 'sailors'. This "monophthongization" overrides ("precedes") vowel truncation (3). Similarly, the segment $u$ is not truncated if the case suffix consists of a single vowel (cornu-a 'horns', portu-i 'to a port'), possibly because here $u$ becomes a glide (-Syllabic) and so escapes (3).

${ }^{4}$ In some forms, stem-final $u$ can survive, yielding e.g. tribubus 'to tribes'. instance, the regular Spanish $1^{\text {st }}$ person singular suffix $-o$ erases the final vowel segment of a verb stem $(a, e$ or $i) .{ }^{5}$ The English suffix -ese, though far from productive, provides another good example of such truncation. It eliminates a preceding schwa syllable in a stem (Burmese, Chinese, Guyanese, Lebanese, Maltese, Portuguese, Viennese) but leaves other stem vowels intact: Cantonese, Congolese, Faroese, Japanese, Nepalese, Senegalese, Sudanese.

Nonetheless, allomorphy as in (3) (nauta/naut-, bello/bell-) somehow struck traditional scholars as too abstract, and so Latin noun stems came to be analysed as consisting rather as almost invariably having final consonants, with following vowel segments taken as part of the case/number inflections: "The stem is that part of the word which remains the same in spelling throughout the declension" (Henle, 1945, p. $5) .{ }^{6}$ As a result, the vowel-final stems in (2) are not at all what one finds in traditional accounts. At best, stell- 'star' is said to be in the Latin-particular and purely morphological 'a declension' (Stock 1971), which means that this consonant-final stem must arbitrarily be followed by 10 case/number allomorphs which usually begin with $a$. Since for Stock there are six such regular declensions, there are 60 regular case/number allomorphs, thus confirming the expectation of Autonomous Morphology (1). But the fatal weakness of this logic is that it is constructed circularly, by an a priori refusal of justified phonological analyses as in e.g. (3).

Because each stem-final noun segment of Latin (taking all consonants as one undifferentiated group) has a unique feature make-up and hence participates differently in stem-suffix allomorphy, it has been

${ }^{5}$ For analyses of Spanish using stem-final vowel truncation, consult Bermúdez-Otero (2007). Halle and Nevins (2009) use a similar approach to Slavic inflection, attributing the basic idea to $\mathrm{R}$. Jakobson. It seems to me, however, that truncation does not apply to the front vowels $i$ and $e$, given e.g. fili-a 'daughter' and re-i 'of a thing'.

6 This dictum is pivotal for metamorphosis of stem-final vowels into case endings. But even replacing "spelling" with "pronunciation", the quote is linguistic nonsense. By this criterion the stem of leaf would be lea-, that of German frau 'woman' would be $\mathrm{fr}$-, that of American English eat would be $\varnothing$ (since e.g. ate and eaten have no segment in common), etc. 
concluded that each should define a separate classification of noun suffixation, or "declension". The six declensions result from the fact that there are basically six types of final segments $(a, o, u, i, e$ and consonants), each gives rise to a different declension, though stems with final $i$ are often put in some other group or considered irregular. $^{7}$

If on the other hand, we accept the existence in Latin of plausible phonological rules such as Final Vowel Truncation (3), we can find some very simple representations for the various case/number inflections, and end up with only a few instances of genuine allomorphy. That is, as in most modern analysis, allomorphy which is perhaps "natural" but not derived from phonology, what is called "phonologically conditioned morphological allomorphy, is relatively rare, not the general rule as in a traditional Latin grammar.

\section{The Latin ablative}

This essay will show that the stems proposed above in (2) can provide relatively simple analyses of all the five Latin cases (and, in fact, allow us to reduce them to four - the same four as found in e.g. Classical Greek, German, Icelandic and Old English). For example, these stems are entirely transparent in ablative singulars (the nature of this case will be discussed immediately after giving its form). For all nouns, this ablative singular ending is uniformly a single vocalic mora (Spaelit 2004) phonetically realized as length on stem-final vowels and as a final epenthetic $\breve{e}$ after stem-final consonants.

(4)

\begin{tabular}{|c|c|c|c|}
\hline Ablative & Stems: & $\begin{array}{c}\text { Glosses: } \mathrm{n} \\
\text { Singulars: }\end{array}$ & $\begin{array}{c}\text { Traditional } \\
\text { declension } \\
\text { names: }\end{array}$ \\
\hline turrī & turri- & tower & $\begin{array}{c}3^{\text {rd }} \text { or “ } i- \\
\text { declension" }\end{array}$ \\
\hline manū & manu- & hand & $4^{\text {th }}$ \\
\hline$r \bar{e}$ & $r e-$ & thing & $5^{\text {th }}$ \\
\hline
\end{tabular}

7 The detailed discussion of the relation of consonant stems to $i$-stems in Cser, to appear: Section 3) is enlightening, and explains why their case/number endings are identical in all but five forms. His decision to treat the variation as "heteroclisy" seems well justified: "Some nouns display forms based on two different stems... and it is understood that certain lexical items shift between these stem types."

\begin{tabular}{|c|c|c|c|}
\hline equō & equo- $^{8}$ & horse & $2^{\text {nd }}$ \\
\hline puerō & puero- $^{\text {nd }}$ & boy & $2^{\text {nd }}$ \\
\hline stēllā & stēlla- & star & $1^{\text {st }}$ \\
\hline labōre & lābor- & work & $3^{\text {rd }}$ \\
\hline flūmine & flūmin- $^{\text {rd }}$ & river & $3^{\text {rd }}$ \\
\hline lēge & lēg- & law & $3^{\text {rd }}$ \\
\hline urbe & $u r b-$ & city & $3^{\text {rd }}$ \\
\hline
\end{tabular}

What exactly is the Latin "ablative"? The very name gives the impression that Latin morphology is "special", since this case name rarely appears in traditional inventories of case systems in other languages. Yet the main role of the Latin ablative is exactly that played by the dative in familiar four-case languages such as Classical Greek, German, Icelandic and Old English. In these languages, Locative (not Directional) Prepositions and Prepositions denoting "motion from" assign "dative case" to their object DPs, where dative is the traditional name for the case of NPs that are "bare" (P-less) indirect objects. Thus:

(5) Latin P-marked case. The Latin ablative is the unmarked case assigned by the category $P$.

In fact, Latin largely conforms to the pattern that P-less indirect objects and objects of unmarked Ps have the same case. In particular, the following robust syncretism (6) holds for all Latin plurals; this striking fact is invariably noted but completely accidental in traditional accounts.

(6) Ablative-dative syncretism. Latin ablatives and datives without exception have the same plural forms.

This syncretism strongly suggests that datives and ablatives must be sub-cases of a single syntactic Case. ${ }^{9}$ The unique additional

${ }^{8}$ Stem-final $o$ changes to $u$ in nominative and accusative singulars because Latin short $o$ generally becomes high $(u)$ in final closed syllables. Raising of short mid vowels spreads to other contexts in later Latin. The text will refer to this note when $u$ replaces stem-final $o$.

9 A reviewer suggests that I make the typographical distinction reflected in most syntactic literature since 1980 between "Abstract Case" and "morphological case". Since I think it is rare that (except for "ablatives") the two don't coincide in Latin, at least where case is morphologically realized, I capitalize Case only when it clearly refers to a unit in a formalized system of synaptic features. In fact, it is a 
dative singular suffix $-\bar{T}$, to which the next section returns, results from a syntactic configuration of particular PPs with covert (unpronounced) head Ps. Except for this, the Latin ablative is the straightforward counterpart of the P-assigned datives of Classical Greek, German, Icelandic and Old English; this includes several uses of "bare ablatives" whose Ps are silent; thus Latin ablatives of agent, degree of difference, manner, means, etc. (Henle, 1945, pp. 173179) translate Classical Greek bare datives with the same functions. It remains only to specify how Latin "bare" indirect objects come to have a special "dative singular" case ending which for most nouns differs from the ablative.

Returning now to case forms, we saw just above that Latin ablative singular inflections uniformly consist of an added final mora (= syllabic segment) on stems. This mora either lengthens a stem-final vowel or is an epenthetic final -e after a stem-final consonant; cf. examples in (4) and the Appendix. The lexical representation of this morpheme is thus a single vocalic segment lexically unspecified for quality. ${ }^{10}$

\section{(7) Latin P-assigned singular case:}

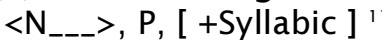

Traditional accounts in which stem-final vowels are parts of inflections hopelessly obscure this simple phonological pattern by analysing five different stem vowels as five separate allomorphic inflections!

For the plural counterpart to (7), we find nonetheless an irreducible pure phonological allomorphy between two separate ablative/dative suffixes, $-\bar{s}$ s and-ibus. An optimal statement of the alternation requires the hypothesis of Spaelti (2004) by which Latin $e$ acts phonologically as a mid vowel, while $o$ acts as a low vowel. The plural suffix for P-assigned case after stems ending in low vowels is then $-i s$ (the traditional " $1{ }^{\text {st }}$ and $2^{\text {nd }}$ declensions"), while after all other final

parsimonious virtue of the framework here that the two concepts can be collapsed.

${ }^{10}$ Notice that the category name for the inflection itself is $P$ and not some morphology-specific name such as "dative" or "ablative." Such traditional names, uncritically taken over into generative grammar, are ad hoc and obscure their basis in syntax. This practice is discussed in the next section.

1 The venerable feature Syllabic from Chomsky and Halle (1968) is needed elsewhere in the system here; see notes $3,20,24$, and 25 . It is therefore not ad hoc. segments (in all other "declensions") it is ibus.

The lexical format for inflections developed in Emonds (2000: Ch. 4) then permits a unified statement of all Latin P-assigned or "ablative" endings on nouns. These ablative suffixes alternatively realize the category $P$ and if present the feature $+P L$.

(8) Latin P-assigned case ("ablatives"):

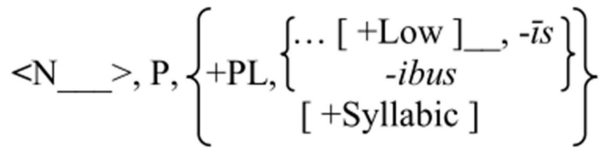

In this entry, all the conditioning factors use either independently justified syntactic ( $P$, $\mathrm{PL})$ or phonological features. No autonomous morphological category is needed.

\section{An interlude: the syntactic basis of cases}

Nothing shows more strongly the unconscious grip of Latin-based tradition on current linguistics than the generally accepted cross-linguistic nomenclature used for syntactic Cases. The names themselves (nominative, genitive, etc.) have no linguistic basis outside of this tradition. For example, the seven cases of Czech not only use these terms for five of the cases but actually order them (nominative, genitive, dative, accusative) in the same arbitrary way, an ordering that reveals nothing about the syncretic groupings in either language (e.g. between nominatives and accusatives).

Although generative analyses often continue to pointlessly use these arbitrary labels, Chomsky (1981: Ch. 3) made significant progress in motivating case as basically syntactic (rather than semantic, morphological, or phonological). The basic (but not only) way that a Noun Phrase receives case (Abstract Case) is from the lexical head category of which it is the sister (i.e. object) or specifier (i.e. subject). In this scheme, the traditional case names have no role other than convenient mnemonics. Thus:

\section{(9) Inventory of basic Case assigners:}

a. The finiteness head (usually today notated as T or I) assigns "nominative" to the Noun Phrase in the Specifier of T/I.

b. The $V$ head of a Verb Phrase assigns "accusative" Case to its Noun Phrase sister.

c. The $P$ head of a Prepositional Phrase assigns oblique Case (in traditional terms 
often given other names) to its Noun Phrase sister.

d. Some head in extended Noun Phrases assigns genitive to its Noun Phrase sister or specifier. The most likely candidate is the Quantifer/Numeral Q (Veselovská, 2001).

Sub-categories of the basic Case assigners often assign marked rather than standard cases. Thus, Japanese stative verbs assign nominative rather than accusative to their objects; Russian negated verbs assign genitive rather than accusative; prepositions of "motion toward" or goal assign accusative to their object in many Indo-European languages, etc. This paper will not be concerned with these variants, except as they affect Latin.

In my view, cases such as accusative and nominative are then nothing other than the categories $\mathrm{V}$ and $\mathrm{T} / \mathrm{I}$ realized as noninterpretable features, namely as inflections under Ns (Emonds 1985: Ch. 1). Features such as Case in positions where they are not interpreted I treat as "alternative realizations." Gender on the other hand is an interpretable feature of noun stems (Ritter, 1993). A surface mini-tree with Case and Gender features for the undifferentiated Latin "nominative" or "accusative" plural lēgēs 'laws' is thus as follows:

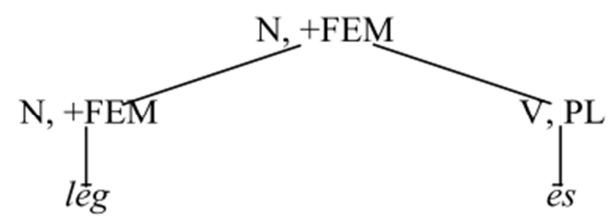

The case suffix labelled $V$ in this mini-tree "alternatively realizes" an external interpreted head $V$ that selects an extended projection NP, of which $\mathrm{N}$ is the lexical head. The suffix's PL (= plural) feature also alternatively realizes under $\mathrm{N}$ the interpreted $\mathrm{PL}$ of some higher functional head (possibly Q) in this NP.

More generally, alternative realization is a tree-based syntactic option that I claim accounts elegantly for almost all of what grammatical tradition generally calls inflection, as well as many grammatical properties of seemingly special free morphemes (e.g. finite forms of the English copula). Extensive justifications are provided in Emonds (1987; 2000, Ch. 4-6).

(11) Alternative Realization (“AR").
A syntactic feature $F$ interpretable in LF on a category $\beta$ can be alternatively realized in $a$ closed class morpheme under $\gamma$, provided that some projections of $\beta$ and $Y$ are sisters. ${ }^{12}$

Thus, Case assigning categories $\mathrm{V}$ and $\mathrm{P}$ (= $\beta$ ) are sisters to NPs, and the heads of these NPs are the $y$ under which (uninterpreted) alternative realizations of $\mathrm{V}$ and $\mathrm{P}$ (taken as features) spell out as closed class morphemes, e.g. as case inflections under $\mathrm{N}$ in (10).

There are two varieties of AR, what I call "marked" and "unmarked". Consider for example English finite verbal inflections ($s / \varnothing$ and $-e d$ ), which alternatively realize respectively the number $\pm P L$ of a subject Noun Phrase and the feature +PAST of the finiteness category T/I. English finite verbs are specified for $\pm P L$ whether or not their subject is overt. Let us call this "doubling" or "standard" AR of the feature PL. On the other hand, +PAST is alternatively realized as a suffix on $V$ only if I is empty (not spelled out as a modal or auxiliary). Let us call this "complementary" AR. ${ }^{13}$ To indicate that a feature realizes complementary AR (e.g. +PAST for English -ed), the feature is underlined in its lexical entry.

Most Latin case-inflected NPs usually cooccur with overt Case-assigners, i.e. Latin case exemplifies standard AR, though nothing prevents Case-assigners from sometimes being empty. ${ }^{14}$ As the next section will show, one instance of Latin casemarking also exemplifies complementary $A R$.

\section{Latin dative singulars}

A remarkable but rather unremarked hypothesis of Chomsky's (1981: Ch. 3) Abstract Case theory proposed that a "fourth Case" is assigned by the category P to object NPs inside PPs. This contrasts with the traditional practice of defining cases on

12 Using a different term "Merger," Halle and Marantz (1993) also argue for using this concept in analysing inflection.

${ }^{13}$ English verbal agreement contrasts with that on Welsh verbs, which in one dialect agree with only covert subjects. Welsh agreement of this type thus exemplifies complementary AR.

${ }^{14}$ A null present subjunctive I of Modern English assigns nominative (Mary insists that we/ "us $\left[\begin{array}{l}\boldsymbol{1} \\ \varnothing\end{array}\right.$ I not be late) and covert Ps assign case to "bare NP adverbials" (Next time please go $\left[\begin{array}{l}\varnothing \\ \text { w this }\end{array}\right.$ way). 
semantic grounds, i.e. dative is the "case of indirect objects".

Chomsky's proposal describes extremely well the "dative" case of (Classical) Greek, German and Icelandic, since in these languages indirect objects and objects of most Ps are in the same case, traditionally named dative. ${ }^{15}$ While Latin has separate cases for the two uses ("datives" for indirect objects and "ablatives" for objects of Ps), as stated above, these two cases are always identical in Latin plurals, strongly suggesting that they are variants on one basic fourth Case. Traditional grammar seems to reserve the name "dative" for indirect object case, while case names of objects of locational and other Ps vary, e.g. in Czech they are "locative" and "instrumental." Hence I prefer a neutral cover term "oblique case" for P-assigned cases, but of course keeping in mind the names used in language-particular grammatical traditions.

There are several (often unrecognized) advantages in attributing oblique cases to PP structure. Studies of diverse languages remark that floating quantifiers and secondary predicates inevitably fail to modify oblique case NPs, including "bare" indirect objects or "bare NP adverbials." This is clearly because NP objects in PPs, whether or not $P$ is overt, fail to c-command such constituents and so cannot be modified by them (Emonds, 1987). In addition, these oblique NPs, often labelled as bearing "semantic case" or "intrinsic case," cannot become nominative, agreeing subjects of passive verbs. This recurring pattern is also easily attributed to a containing PP, since these PPs can be taken as phrasal domains inside which NPs must receive case before being available for movement in larger domains such as TP/IP. For further justification of using Ps and PP structures to assign oblique cases, see Emonds and Ostler (2006). ${ }^{16}$

15 In all three languages, as well as Latin and Czech, objects of overt Ps expressing direction toward are in the accusative; see note 30 .

${ }^{16}$ Babby (1980) and Larson (1985) shied away from covert PP structure as a source of bare oblique case, despite the latter's explanatory advantages. Rather, it again adhered to traditional
The Latin fourth case, its "ablative," like Germanic and Greek datives, is then assigned by $P$, while its singular indirect objects have separate forms called the "dative."

Latin grammars regularly observe that its dative NPs never follow overt Ps, even though the properties listed above suggest a PP source for these "bare NP" datives. In the AR framework, there is no paradox. Rather, Latin dative case exemplifies complementary rather than standard $A R$, in particular of the feature GOAL. That is, only if $P$ is empty does $[\mathrm{P},+\mathrm{GOAL}]$ assign dative (to singular NPs). ${ }^{17}$

\section{(12) Latin dative singular suffix:}

$$
<\mathrm{N}_{---}>, \mathrm{P},+\underline{\mathrm{GOAL}},-\mathrm{PL}, \ldots[- \text { [-Round }]_{---},-\bar{T}
$$

In earlier Latin, only $o$-stems were exempt from this special marking, while in later Latin so also were u-stems (Stock 1971: 13). ${ }^{18}$ The entry (12) expresses the later situation.

Recall that feature underlining indicates complementary $A R$, requiring $[\mathrm{P}, \mathrm{GOAL}]$ in its interpretable position (as head of PP) to be null, exactly the property that appears to characterize the Latin dative. Since this statement is more specific than the default entry for P-assigned case

(8), it takes precedence over it, so

(8) then remains the default Latin specification for oblique case.

Latin descriptive practice, adopting the idea of the Indo-Europeanist Whitney (1889) that oblique case-marked NPs are independent of syntactic structure (so-called inherent case).

17 Latin expresses NPs of purpose, possession, and in poetry sometimes physical GOALs with bare datives (Henle 1945: 161-165). This is natural in the approach here, since datives can arise only when $[P, G O A L]$ is empty.

18 The entry (12) suggests the basis of this change. The early Latin dative singular $-\bar{i}$ didn't appear after stem-final $o$, which is a segmentspecific statement. This condition generalized to lack of $-\bar{T}$ after both round vowels, an extension to a phonologically natural class, unexpected in declensional accounts. 
(13) P-assigned case allomorphs in Latin: ${ }^{19}$

\begin{tabular}{|c|c|c|c|}
\hline $\begin{array}{l}\text { Stem-final } \\
\text { segments and } \\
\text { examples }\end{array}$ & $\begin{array}{c}P,+P L U R A L: \\
\text { see rule ( } 3) \text { for loss } \\
\text { of stem vowels }\end{array}$ & $\begin{array}{c}\text { P, -PLURAL: } \\
\text { ablatives (and datives } \\
\text { after } 0 \text {-stems) }\end{array}$ & $\begin{array}{cl}\text { P, } & \text {-PLURAL: } \\
\text { datives } & \text { except after } o \text { - } \\
& \text { stems }\end{array}$ \\
\hline After low vowels $(a, o)$ & Add $-\bar{I} S$ & \multirow[b]{2}{*}{$\begin{array}{c}\text { Add a }+ \text { Syllabic } \\
\text { segment }\end{array}$} & \multirow[b]{2}{*}{$\begin{array}{l}\text { Add }-\bar{i} \text { to the stem, } \\
\text { using lexical entry (12) }\end{array}$} \\
\hline $\begin{array}{l}\text { After non-low vowels } \\
(i, u, e) \text { and } \\
\text { consonants }\end{array}$ & Add -ibus & & \\
\hline turri- 'tower' & turribus & turrī & turrī $(i \bar{T} \rightarrow \bar{I})$ \\
\hline portu- 'harbour' & portibus & portū & portuī \\
\hline$r e$ - 'thing' & re-ibus $\rightarrow$ rēbus & $r \bar{e}$ & $\operatorname{Re} \bar{\top}$ \\
\hline urb- 'city' & urbibus & urbe & Urbī \\
\hline lābor- 'work' & lāboribus & lābore & Lāborī \\
\hline lēg- 'law' & lēgibus & lēge & Lēgì \\
\hline flūmin- 'river' & flūminibus & flūmine & Flūminì \\
\hline nauta- 'sailor' & nautīs & nautā & nauta-I $\rightarrow$ nautae \\
\hline servo- 'slave' & servīs & & \\
\hline
\end{tabular}

${ }^{19}$ This table does not indicate the Late Latin change of portuī to portū. The forms rēbus and nautae are later Latin monophthongs of earlier reibus and nautaĩ.

Table (13) shows that Latin P-assigned Case involves at most 2 singular and 2 plural allomorphs. In P-assigned plurals, -ibus alternates with $-\bar{s} s$ (column 2), and the alternation is phonologically conditioned. In singulars the regular allomorph is an additional vocalic mora (column 3 ) and the other is a syntactically conditioned dative singular suffix (column 4). This transparent system is formulated in standard terms of generative syntax and phonology and captures all the relevant generalizations. It is far superior to declensional paradigms, which could equally well accommodate 2024 distinct forms, and in which it is simply an accident that there are only four distinct forms.

5. A preliminary for other cases: the Lexical Parentheses Convention

Nouns in Latin frequently distinguish nominative singular forms from stems used in plural and other singular cases, which have a final segment that the nominative singular lacks. Among its inflections, one allomorph can have an initial segment lacking in the other, e.g. the genitive plural suffix -(r)um. Similar variations are found in other languages, which provide ample evidence that underlying lexical representations must allow for a certain kind of "optional segment".

For example, many Japanese verbal suffixes appear in two forms, widely represented informally by the use of parentheses: - $(r) a r e$ 'passive', -(s)ase- 'causative', -(i)ta- 'want to', -(a)na- 'not', - $(r) u$ 'present tense', etc. The parentheses express the idea that the enclosed segments appear for enhancing the recurring universal pattern of consonantvowel alternation. Thus the Japanese inflected present tenses on the roots tabe'eat' and nom- 'drink' are respectively tabe$\boldsymbol{r} \boldsymbol{u}$ and nom-u, and similarly their causative forms (followed here by past tense inflection -ta) are tabe-sase-ta and nom-ase-ta. When the inflection on the other hand has an initial parenthesized vowel, the underlying forms (here with present tense) are respectively the desideratives tabe-ta-i 'want to eat' and nom-ita-i 'want to drink', with their present tense negatives being tabe-na-i and nomana-i. The parenthesized segments are thus used to avoid non-alternating CC (biconsonantal) or $\mathrm{VV}$ (bi-vocalic) sequences.

Formally, we can formally define such parentheses as follows:

(14) Lexical Parentheses Convention. In lexical phonological forms $\pi=\alpha(\beta)$ or $(\beta) \alpha, \beta$ is inserted in $\alpha_{--} \delta$ or $\delta_{--} \alpha$ if and only if the two context segments $\alpha$ and $\delta$ (in contrast to $\beta)$ are specified the same for \pm Syllabic ${ }^{20}$

20 C. Piera (pers. comm.) suggests using the feature Consonantal rather than Syllabic in (14). However, in another use of (14), the lexical representations of stem-final $u$ and $i$ and of inflection-initial $u$ should not agree in all features, yet all are -Consonantal. I will argue there that Latin stem-final $u$ and $i$ are lexically neutral between being vowels or glides, which is expressed directly by lack of lexical specification for \pm Syllabic. 
Other clear examples of this type of lexical entry are: (i) The English indefinite article, which can be notated $a(n)$; then $-n$ will occur after $a$ if and only the following pronounced segment $\delta$ is a vowel. (ii) Final consonants of many (by no means all) French adjectival roots are pronounced only if they precede a (lexically) vowel-initial bound morpheme, such as the nominalizers -ie or -eur or the feminine agreement "mute $e$ " suffix: bas 'low', bass-e (+FEM), bass-esse 'lowness'; froid 'cold', froid-e (+FEM), froid-eur 'coldness'; haut 'high', haut-e (+FEM), hauteur 'height'. ${ }^{21}$ These well-known alternations imply that something like the Lexical Parenthesis Convention is a necessary part of what is often discussed under the rubric of an Obligatory Contour Principle.

It turns out that Latin, like many other languages, uses the Lexical Parenthesis Convention (14). This is particularly evident in many forms given in Table (1) in Cser (to appear: Section 2.1) for Latin verbal suffixes: -(e)nt- 'active participle', -(e)nd- 'passive participle', -(e)re 'active infinitive', $-(r) \bar{T}$ 'passive infinitive', -(i)te 'plural imperative', (e)rē- 'present subjunctive', -erā 'past subjunctive', -(i)stis ' 2 nd plural perfect', etc.

This principle of lexical representation also allows us to simplify what traditional works take as irregular case-inflection on many Latin nouns. The nouns in question alternate between a truncated stem in the nominative singular, usually with a nominative case suffix $-s,{ }^{22}$ and a full stem for all other cases, whose inflections begin with a (sometimes epenthetic) vowel. Some example stems are aetā $(t)$ - 'ancient times', ar(t)- 'art', fon $(t)$ 'spring', lapi(d)- 'stone', lau(d)- 'praise', limi(t)- 'frontier', men $(t)$ - 'mind', pe(d)- 'foot', requie(t)- 'rest', rātiō(n)- 'reason', sangui(n)'blood', $\operatorname{sermo}(n)-$ 'speech', $\operatorname{virtu}(t)$ 'courage', and with irregular plurals bo(v)'cow'. ${ }^{23}$

P. Spaelti (pers. comm.) kindly clarified for me the range of relevant Japanese suffixation patterns relevant to (14), specifically excluding the past tense as requiring a different treatment.

${ }^{21}$ The initial vowels in these suffixes, especially "mute $e$ " is unpronounced in many contexts in Standard French, but this vowel robustly surfaces in southern dialects and in some heavily consonantal contexts.

${ }^{22}$ The conditioning factor that chooses between nominative $-s$ and $-\varnothing$ is given in Section 8 .

${ }^{23} \mathrm{~A}$ reviewer indicates that loss of $t / d$ before $s$ is different, so that to the extent it is phonologically
Applying (14) to stems with parenthesized segments, we straightforwardly obtain many nominative-genitive pairs listed as "irregular" in traditional Latin handbooks: bō-s/ bov-is, lau-s/ laud-is, lac- $\varnothing /$ lact-is, pē-s/ ped-is, rātiō- $\varnothing /$ rātion-is, sangui-s/ sanguin-is, sermō-Ø/ sermon-is, requiē-s/ requiēt-is, virtu-s/ virtut-is, etc. ${ }^{24}$ Using the crosslinguistic Lexical Parentheses Convention has the effect of removing a cornerstone in traditional lore of Latin morpho-syntax, namely special lists of "exceptional" nominative/genitive pairs such as lapis/lapidis. These pairs are not special characteristic of Latin case; they are rather just the normal results of Latin nouns having lexical entries like Japanese verbal suffixes and French adjectival roots.

\section{Latin genitive inflections and the use of lexical parentheses}

Studies of languages both in and outside of the Indo-European reveal that a dedicated grammatical mark, usually called genitive case, sets off nouns and noun phrases that are modifiers or complements of other nouns. In fact, the Indo-European genitive is somewhat special in having extensive uses outside of noun-headed domains - for example to signal "direction from" with verbs of motion. In Greek and Czech, for example, objects of Ps expressing direction away from are in the genitive. But even in IndoEuropean, genitive case's central function is to indicate a noun (phrase) that is subordinate to a head with a nominal feature, perhaps $Q$, as noted in (9). In any event, as we are focusing on the forms rather than the uses of Latin cases, we need

general and regular, these stem-final $(d)$ and $(t)$ may not need to be specified in lexical entries.

24 The formulation (14) suffices for most examples in the text. Nonetheless, the principle seems more general; suggesting that the feature "Syllabic" should be replaced by something like "the most general feature differentiating $\alpha$ and $\beta$," which is indeed often \pm Syllabic. But for alternating lexical stems of other nouns such as men(t)- (men-s 'mind'), cor(d)- (cor 'heart') and fon(t)- (fons 'fountain'), the most general difference between the bold segments $\alpha-\beta$ is \pm Sonorant. So in this case, an obstruent $\beta$ inserted before vowel-initial inflections breaks up adjacent sonorants: ment-is, cord-is, font-is. A refinement of (14) should also account for alternations like nox/noctis 'night' with a lexical stem noc(t)-. 
not discuss further the different distributional properties of genitives; cf. Emonds (2009).

A crucial factor in both singular and plural morphology of Latin genitives is whether a stem-final segment has the feature $+\mathrm{High}^{25}$ This contrasts with P-assigned cases, where suffixal allomorphy depends on the stemfinal feature \pm Low, as seen in their lexical entry

(8). The genitive endings after stem-final High vowels, seen in (15), are $-\bar{T}$ in the singular and -rum in the plural.

\begin{tabular}{|c|c|c|}
\hline Stems: ${ }^{26}$ & $\begin{array}{c}\text { Genitive } \\
\text { singulars, }-\overline{-} \text { : }\end{array}$ & $\begin{array}{c}\text { Genitive } \\
\text { plurals, -rum: }\end{array}$ \\
\hline $\begin{array}{l}\text { nauta- } \\
\text { 'sailor' }\end{array}$ & $\begin{array}{c}\text { nauta-i }(\rightarrow \\
\text { nautae })\end{array}$ & nautā-rum \\
\hline equo- 'horse' & $\begin{array}{l}\text { equo-i } \rightarrow \text { equī } \\
\text { by rule (3) }\end{array}$ & equō-rum \\
\hline bello- 'war' & $\begin{array}{l}\text { bello-i } \rightarrow \text { bellī } \\
\text { by rule (3) }\end{array}$ & bellō-rum \\
\hline puero- 'boy' & $\begin{array}{l}\text { puero-ī } \rightarrow \\
\text { puerī by rule } \\
\text { (3) }\end{array}$ & puerō-rum \\
\hline$r e$ - 'thing' & $r e-\bar{T}$ & rē-rum \\
\hline
\end{tabular}

For all other stem-final segments, genitive singulars use -is after consonants and -s after vowels. Since one motivation for the Lexical Parenthesis Convention (14) is its use in specifying suffixes (on Japanese verbs), it is very well-suited for lexically representing the Latin genitive singular suffix as -(i)s. In fact, it also accounts for the genitive plural suffix -(r)um. ${ }^{27}$

${ }^{25}$ A better alternative might replace -High with a lexical feature +Syllabic, since $i$ and $u$ in Latin lexical entries may inherit from Indo-European $a$ lack of specification for Syllabic. If so, all and only non-high vowels are lexically +Syllabic, and all other segments then form a default or elsewhere class.

${ }^{26}$ These forms also show that stem-final vowels become long in genitive plurals, as they also do in nominative plurals; I don't formalize a description of this lengthening here.

27 The suffix -ium seems to replace -um after those double consonants not analysed as a syllable-initial group: gent-is 'of a tribe'/ gent-ium 'of tribes'; part-is 'of a part'/ part-ium 'of parts'; host-is 'of the enemy'/host-ium 'of enemies', as well as other forms not listed here (Stock, 1971, pp.15-16). Traditional declensional accounts cannot clarify this alternation, as the problems are all internal to the "third declension".
(16)

\begin{tabular}{|c|c|c|}
\hline Stems: & $\begin{array}{c}\text { Genitive } \\
\text { singulars, -(i)s: }\end{array}$ & $\begin{array}{c}\text { Genitive } \\
\text { plurals - } \\
\text { (r)um: }\end{array}$ \\
\hline flūmin- 'river' & flūmin-is & flūmin-um \\
\hline labor- 'work' & labōr-is & labōr-um \\
\hline lēg- 'law' & lēg-is & lēg-um \\
\hline patr- 'father' & patr-is & patr-um \\
\hline pisc(i)- 'fish' & pisc-is & pisc-ium \\
\hline urb- 'city' & urb-is & urb-ium \\
\hline cord- 'heart' & cord-is & cord-ium \\
\hline $\begin{array}{c}\text { portu- } \\
\text { 'harbour' }\end{array}$ & $\begin{array}{c}\text { portu-s }(\rightarrow \\
\text { portūs) }\end{array}$ & portu-um \\
\hline classi- 'fleet' & classi-s & classi-um \\
\hline
\end{tabular}

The forms in (15)-(16) show that the genitive singular suffix after stem-final -High segments $(a,-o,-e)$ is $-i$, while $-i$ or $-s$ is the default or elsewhere genitive singular suffix for stem-final $i, u$ or consonants. Convention (14) chooses between the latter two, as follows. When the stem-final segment is Syllabic, then $i$ occurs between the stem and -Syllabic s (lēg-is 'of a law', flümin-is 'of a river'), while $s$ alone suffices after the final stem segments $-i$ or $-u$, which are +Syllabic or simply lexically unspecified for this feature. In terms of Convention (14), suppose the sequence $\delta-\beta-\alpha$ is e.g. $u-i-s$. Since $u$ and $s$ are specified differently for \pm Syllabic, $i$ is not inserted: cornū-s of a horn'; turri-s 'of a tower'.

The same reasoning applies for the genitive plural suffix $-(r) u m$ if, as in note 25 , Latin high vocalic segments, like those of IndoEuropean, appear to be lexically unspecified for being vowels or glides. ${ }^{28}$ When a stemfinal segment is a true vowel $(o, e, a)$, then $r$ is inserted to break up the vowel sequence: servōrum 'of slaves', rērum novārum 'of new things', stēllārum 'of stars'. All other stem-final segments are either -Syllabic or unspecified for this feature ( $i$ and $u$ ); the Lexical Parentheses Convention then correctly excludes this $r$, for example in all forms in the right column of (16). This account of an otherwise puzzling alternation suggests the following single lexical entry (17). As in (9), Q stands for the Alternative Realization of the category in noun phrases that assigns genitive case.

${ }^{28}$ A reviewer notes that underspecified segments may well cause problems for theoretical treatments of phonotactics and metrics. While true, my reaction is that these treatments should not be based on lexical entries, but on more superficial phonetic or phonological representations. 
(17) Latin genitive plurals:

$<\mathrm{N}_{---}>, \mathrm{Q},+\mathrm{PL},-(r)$ um

The widely accepted brace notation for disjunctive choice allows us to combine this entry for the plural genitive (17) with the genitive singular allomorphs into a single entry (18):

(18) Latin genitive case:

$<\mathrm{N} \_>, \mathrm{Q},\left\{\begin{array}{c}+\mathrm{PL},-(r) u m \\ \ldots[-\mathrm{High}] \_,-\bar{l} \\ -(i) s\end{array}\right\}$

The correctness of (18) for genitive inflection is confirmed by the behaviour of $i$ stem nouns, which Latin grammars often treat as irregular. These nouns, whose ablative singulars turri- reveal the stem vowel, in fact have the regular genitive endings $-s$ and -um: turri-s and turri-um. They are thus regular, and parallel the " $4^{\text {th }}$ declension" u-stems: manu-s, manu-um 'of hand(s)'.

In sum, the Latin genitive alternations depend only on the phonological status of a noun stem's final segment ( $C$ or $V$ ) and the general and cross-linguistic Parentheses Convention (14). It is easily appreciated how the assumption of 5-6 declension classes, where each paradigm has been taken as formally independent of the others, has fully obscured the two simple phonologically conditioned lexical alternations in (17)- (18).

All the results so far, i.e. the entire range of noun inflections for the three oblique Latin cases, can be displayed in a succinct table:

\begin{tabular}{|c|c|c|}
\hline & -PLURAL & +PLURAL \\
\hline $\begin{array}{l}\text { Case-marking category }=\mathrm{Q} \\
\text { (genitives): }\end{array}$ & $\left\{\begin{array}{c}\ldots\left[- \text { High }_{\ldots} \ldots,-\bar{l}\right. \\
-(i)_{S}\end{array}\right\}$ & $-(r) u m$ \\
\hline $\begin{array}{l}\text { Case-marking category }=\mathrm{P} \\
\text { (datives and ablatives): }\end{array}$ & $\left\{\begin{array}{c}+ \text { GOAL }, . . .[- \text { Round }] \\
{[+ \text { Syllabic }]}\end{array},-\bar{\imath}\right\}$ & $\left.\begin{array}{c}\ldots[+[\mathrm{Low}] \ldots,-\bar{l} s \\
-i b u s\end{array}\right\}$ \\
\hline
\end{tabular}

This table allows us to appreciate the important role that generative phonology's basic binary vowel features play in characterizing the allomorphy among Latin case endings. The genitive case allomorphs depend on preceding segments being $\pm \mathrm{High}$, while oblique case allomorphs depend on \pm Round and \pm Low. These features come very close to what Cser (to appear: Section 1) calls a condition of "Contiguity", which he claims is necessary for descriptive and theoretical significance: "If two environments that are not adjacent on the [vocalic] scale select the same allomorph, then all the environments between the two select the same allomorph." Though his notion of vocalic scale is described more in terms of phonetics than of phonology, it should be kept in mind that Chomsky and Halle (1968) insist that phonological features are grounded in phonetic reality. Consequently, their binary features, at least those used here, all do divide the phonetic space into internally contiguous portions, with the effect that each selecting environment in (19) indeed conforms to Cser's Contiguity Condition.

\section{Latin V-assigned cases: singulars and neuters}

7.1 Syncretism of nominative and accusative. The declensional model of Latin case inflections includes 5 to 6 declensions and 2 numbers, leading one to expect up to 24 nominative and accusative suffixes. Since the entire range of Latin $\mathrm{V}$-assigned case contains only 6 separate endings, it is obvious even prior to analysis that declensional lists of inflections can't have any kind of psychological reality. A proper analysis of this morphology must account for why so many sorts of stems have identical $\mathrm{V}$-assigned inflections.

Among the extensive syncretisms of Latin nominatives and accusatives, every Latin grammar remarks that for nouns of "neuter" gender these two cases are always identical. A less discussed pattern is that, except on stems ending in low vowels $-a$ and $-o$, Latin plurals of any gender have identical nominatives and accusatives: portūs 'harbours', rēs 'things', partēs 'parts'. In the Government and Binding Case assignment (Chomsky, 1981: Ch. 3), the finiteness category I/T (henceforth simply "T") assigns "nominative" to NPs in subject position, and 
the category $V$ assigns "accusative case" to direct objects NPs (in the absence of special properties of individual verbs,). It is now widely agreed that both categories have a verbal feature $V$, shared by all heads in "extended projections" of V (for this notion, see Grimshaw 1990. In these terms, [V,-T] assigns "accusative" and $[\mathrm{V},+\mathrm{T}]$ assigns "nominative". For extensive justification of this way of assigning nominative and accusative case, see Emonds (2010). ${ }^{29}$

The syncretic forms can then simply be called instances of "V-assigned case", whereby the combination $[\mathrm{V},+\mathrm{T}]$ assigns any special nominative forms and [V,-T] any special accusative forms. Without the stipulation of $\pm T$, simple case assignment by $\mathrm{V}$ alone predicts the syncretism which stymies traditional accounts. ${ }^{30}$

29 As is well-known and even stressed in traditional treatments, Latin vocative case is not really independent; it differs from the nominative only on singular nouns with a stem-final vowel - $o$, and there is no purely syntactically definable context that assigns it.

${ }^{30}$ In addition to quirky cases assigned by irregular lexical Vs and Ps, Latin and numerous other IndoEuropean languages have many lexical Ps of "direction toward" that systematically assign accusative case to their object N, i.e. Ps specified as +GOAL. Since case is spelled out in the phonological stage of derivations, where the categorial content of a head (such as $\mathrm{P}$ or $\mathrm{V}$ ) plays no central role, these accusatives can simply be specified by a phonological process switching the categories of these $\mathrm{P}$ to $\mathrm{V}$.

(i) PF category change:

(ii) $\quad \mathrm{P} \rightarrow \mathrm{V}$ in lexical items with the feature $+\mathrm{GOAL}$.

In addition, since $P$ is always $-T$, a $V$ resulting from (i) is also -T, i.e. this rule always assign accusative rather than nominative case. So
Besides the traditional approach, a second non-formal approach to case is broadly called "functionalist". That is, different morphological indications (cases) on noun phrases with contrasting semantic roles are motivated by the need to avoid ambiguity and misunderstanding, especially in languages where free order of phrases predominates. From this functionalist perspective, one would expect that the most frequently used and contrasting cases (in single clauses), namely nominatives and accusatives, should be the least ambiguous and the least syncretic. And here again, the non-formal expectations are completely frustrated: the most frequent morphological cases are, at least in Latin, the least differentiated.

7.2 The curious construct of "neuter gender". The clearest division in Latin among $\mathrm{V}$-assigned case inflections, reduced to not much more than passing mention in declensional accounts, is between the neuter nouns, uninflected in the singular and with a uniform plural suffix - $a$, and the non-neuter nouns, which partition nominatives and accusatives using four overt suffixes $s, m, \bar{I}$ and "vowel length $+s$ ". Declension class analyses fail to capture this contrast among the V-assigned case inflections because declensions depend on stem-final segments, which correlate only weakly with gender. Consequently, traditional Latin grammars state separate rules for neuters in addition to the declensions.

We will now see that the special behaviour of "neuter" nouns has a quite different source. We first observe the forms of neuters in positions that the $V$ feature assigns case.

because of this rule, Latin Ps that indicate motion toward a goal, such as ad 'to', in 'into', post 'after', super 'over', assign accusative case exactly as if they were verbs.

\section{(20) Nominatives and accusatives of neuter nouns:}

\begin{tabular}{|c|c|c|}
\hline $\begin{array}{l}\text { Stems with a range of final } \\
\text { segments }\end{array}$ & $\begin{array}{c}\text {-PLURAL: uninflected except after } \\
\text { stem-final } o \text { : }\end{array}$ & $\begin{array}{l}\text { +PLURAL: } \\
\text { invariant }-a\end{array}$ \\
\hline $\begin{array}{l}\text { bello- 'war' } \\
\text { cornu- 'horn' } \\
\text { nōmin- 'name' }\end{array}$ & $\begin{array}{l}\text { bello-m } \rightarrow \text { bellum; } \\
\text { see note } 8 \text { for vowel change. } \\
\text { cornu } \\
\text { nōmen }\end{array}$ & $\begin{array}{l}\text { bello- } a \rightarrow \text { bella; } \\
\text { see rule (3). } \\
\text { cornu- } a \\
\text { nōmin-a }\end{array}$ \\
\hline
\end{tabular}

${ }^{31}$ Several neuter stems (nōmen, caput, rōbur, genus) have different short vowels in final syllables when there is an overt suffix: nōmin-, capit-, rōbor-, gener-. Some of these are unpredictable lexical variants; others can be explained in terms of vowel heights allowed in different types of syllables. 


\begin{tabular}{|c|c|c|c|}
\hline vās- & 'vase' & vās & vās-a \\
\hline rōbor- & 'army' & rōbur & rōbor-a \\
\hline capit- & 'head' & caput & capit-a \\
\hline os: & 'knee' & os & oss -a \\
\hline$v \bar{e} r-$ & 'spring' & $v \bar{e} r$ & $v \bar{e} r-a$ \\
\hline
\end{tabular}

As mentioned above, Latin non-neuter nouns exhibit four different lexical suffixes for nominatives and accusatives. It is unlikely that these lexical entries should include stipulations to exempt "neuter gender" nouns as in (20) from their scope, since elsewhere, gender (neuter or otherwise) plays no role at all in selecting case inflections.

The key to understanding Latin "neuters" actually lies entirely outside the area of gender. The salient syncretism about neuters is that, throughout all of Latin grammar, except for $\mathrm{V}$-assigned case, "neuter" and masculine case forms are identical; see Henle's (1945) sections on adjectival (pp. 14-24) and pronominal forms (pp. 32-39).

In fact, the grammars of Modern German also limit the distinction between "neuter" and "masculine inanimate" to forms for Vassigned case. In both languages, then neuter and masculine forms are identical in the other cases. ${ }^{32}$ This indicates that "gender" is not an appropriate construct for understanding the forms in Table (20). Let us therefore classify Latin so-called neuter nouns as standard masculine inanimates whose special distributional property is related not to gender but to $\mathrm{V}$-assigned case:

(21) Inherent V-case (= "neuter") nouns. A limited subset of lexically masculine nouns can't appear with suffixes for V-case. This is

${ }^{32}$ This paper does not analyse case agreement on Latin adjectives, which is undertaken rather in Emonds (2012). A central idea there is that agreeing adjectives contain an $\mathrm{N}$ infix between the Adjective stem and the case inflection, and that this $\mathrm{N}$ infix, like all Latin nouns, has gender. But in a number of irregular adjectives such as audāx and diligēns, this infix has a zero allomorph in the singular. As a result, no inherent case remains, and so by (21), neuter nominative and accusative singulars must be inflected for case, here the suffix $-s$.

The statement (22) also applies to Czech, with the sole exception that neuter and masculine inanimate nouns have different genitives. Nonetheless, these two Czech genders are identical in all dative, locational and instrumental forms as well as in their genitive agreement forms. because these "neuter" stems have inherent V-Case.

This single statement eliminates the need for any references to " \pm Neuter" in lexical entries for nominative and accusative endings. From this perspective, Latin neuter singulars (except $o$-stems) entirely lack any $V$-case suffixes. This suggests that its uniform "neuter plural" - a spells out only the bare feature +PL under $\mathrm{N}$ whenever stems already have case.

This treatment of neuter gender removes the only significant exception to a general property shared by many case-inflecting languages. Although German does not systematically display case inflection on nouns, Czech and Latin nouns (outside the inanimate masculines under discussion) must exhibit case or number inflection outside of nominative singulars.

(22) Obligatory Inflection Parameter (Latin and (zech among others). Head Ns must be specified with lexical morphemes for all marked values of Case and Number. ${ }^{33}$

This lack of otherwise obligatory case inflection on Latin neuter nouns, due to their inherent lexical case, is less exotic than at first appears. A completely parallel formal phenomenon is seen in English plurals. The regular obligatory plural $-(e) s$ alternatively realizes under $\mathrm{N}$ the feature $+\mathrm{PL}$, whose canonical (interpretable) position is on a functional head such as a Q sister of NP. As is common knowledge, this inflection cannot appear on a limited subset of otherwise countable nouns: those deer / fish / moose / offspring / perch / salmon / sheep / sperm / swine, etc. A plausible account for these "irregular" null plurals is that lexical entries of these stems have an inherent optional +PL feature, which then appears with the $\mathrm{N}$ (or not), depending on what the syntactic context requires:

${ }^{33}$ One allomorph for Czech genitive plurals is unpronounced, but it is arguably structurally present. Latin has no such empty case allomorphs. This paper is not trying to account for detailed aspects of Czech case. 
a. Those three perch("es) were tasty, but one perch was too dry.

b. The corner table ordered three steaks/salmon("s).

c. Those lying swine("s) were standing by the bar.

d. That lying swine was standing by the bar.

Such entries specified as [N, (+PL)] are unacceptable with overt plural suffixes, presumably because the combination would violate Economy by expressing $\mathrm{PL}$ on $\mathrm{N}$ twice, on both the stem and the suffix.

An exactly analogous situation obtains for Latin neuter nouns. They are simply masculine Ns lexically listed with an optional case feature $V$, the common denominator of nominatives and accusatives. This feature can appear with these nouns in trees or not, depending on what case features are required by surrounding syntactic contexts. When present on a masculine noun in positions of nominatives and accusatives, the lexical $\mathrm{V}$-case feature on $\mathrm{N}$ excludes overt case suffixes, which, like the plural suffix with deer, fish, etc., would violate Economy.

Let us now turn to the plurals of Latin neuter nouns. Essentially every grammar of Latin since antiquity has recognized a "neuter plural" rule that ignores traditional declension classes. Informally the rule states: "Every Latin nominative and accusative neuter plural ends in - $a$." Examples include the forms in the right column of Table (20). As we have eliminated neuter gender, this rule simply spells out a plural inflection in the presence of an inherently $\mathrm{V}$-marked noun stem.

\section{(24) V-assigned "neuter" plurals:

$$
<\left[\mathrm{N}, \mathrm{V}_{\text {Case }}\right]_{---}>,+\mathrm{PL},-a^{34}
$$

Declension-based accounts present this rule as an exceptionless generalization that testifies to the regularity and internal logic of Latin grammar. Indeed it does. Moreover, it also starkly reveals the bankruptcy of these very accounts, since (24) has no relation to declension classes. Neuter nouns can be in 3 different declensions $\left(2^{\text {nd }}, 3^{\text {rd }}\right.$, and $4^{\text {th }}$ ) which each contain large non-neuter subclasses as well, so traditional accounts must admit that (24) is actually a glaring "exception" to their declensional paradigms. In terms of this study, (24) strongly supports two of its main hypotheses (i) the common nature of nominative and accusative syntaxbased case marking by $\mathrm{V}$ and (ii) the redundancy and irrelevance of declension classes.

7.3 Accusatives and the enigma of nominative $-s$. For analysing Latin singular V-marked suffixes, we go directly to a chart that shows all their variants:

${ }^{34}$ Like the oblique case plural inflections $-i s /$. ibus, the V-marked plural allomorph - $a$ can bring about truncation of a stem-final back vowel 0 ; thus bella 'wars', not *belloa; cf. rule (3).

\section{(25) Latin inflections for V-assigned case on singular Ns:}

\begin{tabular}{|c|c|c|c|}
\hline \multicolumn{2}{|c|}{$\begin{array}{l}\text { various final segments on (non- } \\
\text { neuter) stems: }\end{array}$} & $\begin{array}{c}\text { accusatives with a uniform - } m \\
\text { suffix }\end{array}$ & $\begin{array}{l}\text { nominatives with }-s \text { or no } \\
\text { suffix }\end{array}$ \\
\hline pleb- & 'commoner' & pleb-e-m & pleb-s \\
\hline$u r b-$ & 'city' & $u r b-e-m$ & $u r b-s$ \\
\hline$O P-$ & 'help' & $o p-e-m$ & $o p-s$ \\
\hline pac- & 'peace' & pac-e-m & pac-s $(=p a x)$ \\
\hline lēg- & ‘law’ & lēg-e-m & $\operatorname{leg}-s(=\operatorname{lex})$ \\
\hline hiem- & 'winter' & hiem-e-m & hiem-s \\
\hline $\operatorname{virtu}(t)-$ & 'strength' & virtūt-e-m & $\operatorname{virtū-s}$ \\
\hline $\operatorname{men}(t)-$ & 'mind' & ment-e-m & $m e \bar{n}-s$ \\
\hline$b o(v)-$ & 'cow' & bov-e-m & $b \bar{o}-s$ \\
\hline $\operatorname{lau}(d)-$ & 'praise' & laud-e-m & lau-s \\
\hline portu- & 'port' & portu-m & portu-s \\
\hline turri- & 'tower' & turri-m & turri-s \\
\hline$r e-$ & 'thing' & $r e-m$ & $r e-s$ \\
\hline equo- & 'horse' & equo-m $\rightarrow$ equum; & equo-s $\rightarrow$ equus \\
\hline
\end{tabular}

${ }^{35}$ The epenthetic segments $-e$ - in (25) are due to Latin not tolerating final obstruent sequences; see the Appendix. 


\begin{tabular}{|ll|l|l|}
\hline puer(o)- & 'boy' & see note 8. & puer \\
agr(o)- & 'field' & ag-e-r \\
stēlla- & 'star' & agro-m $\rightarrow$ agrum & Nuerum \\
labor- & 'work' & stēlla-m & labor suffix; see \\
sōl- & 'sun' & labor-e-m & sōl below. \\
rātio $(n)-$ & 'reason' & sōl-e-m & ratio \\
& & rātion-e-m & \\
\hline
\end{tabular}

Recall that parenthesized stem-final consonants are subject to the Lexical Parentheses Convention (14). A parenthesized stem-final segment after a consonant can also be a vowel. In this situation the vowel surfaces only in nominative singulars, since in other cases this consonant itself is differently specified for \pm Syllabic than the initial vowels of the inflections (whether lexical or epenthetic). Thus lexical representations of various nouns such as coll(i)- 'hill', fin(i)- 'end', $n a \bar{v}(i)$ 'ship', orb(i)- 'circle' give rise to often identical nominative-genitive pairs, though the divisions between stem and suffix are different: colli-s, coll-is; fini-s, fin-is; nāvi-s, nav-is; orbi-s, orb-is. Though these nouns straightforwardly exemplify the Lexical Parentheses Convention, handbooks often list them as "exceptions". ${ }^{36}$

I now formulate lexical entries for the suffixes $-m$ and $-s$ in (25). It is such entries which had a mental reality for Latin speakers, not the redundant paradigms of traditional morphology. The single accusative singular suffix is specified by the following lexical entry:

(26) Latin accusative (tentative): $<\mathrm{N}_{---}>,-\mathrm{PL}, \mathrm{V},-\mathrm{T}, \mathrm{m}$

When this entry inserts $m$ on a consonantfinal stem, a process of phonetic epenthesis adds a short $e$ before $m$, giving rise to the syllable -em at the end of many stems in (25). But the underlying form of this inflection exhibits no declensional allomorphy whatever. Once the vowels

${ }^{36}$ Unsurprisingly, usage fluctuated for some noun stems with identical nominatives and genitives. For instance, the lexical representations nāv(i) 'ship' and ign(i) 'fire' yield ablative singulars nāve and igne, while the lexical stems nāvi and igni yield instead nāvī and ignī. According to Stock (1971), both patterns are attested. A few truly exceptional contrasts between stems and nominative singulars of course remain, such as iter, itineris 'way', Juppiter, Jovis 'Jupiter'. But the number of true irregularities is far less than the impression given in Latin grammars. traditionally taken to distinguish declensions are reanalysed as parts of stems, a single lexical entry such as (26) easily captures the invariant character of the accusative singular inflection.

As also seen in Table (25), neuter (= inherently case-marked) o-stems exceptionally employ this suffix $-m$ in singulars, with no effect on other so-called $2^{\text {nd }}$ declension nouns. The braces in (26) capture the fact that $-m$ is uniformly the singular inflection for accusative case, as well as a suffix on a phonological sub-class of inherently case-marked stems:

\section{(26) Latin accusative singular suffix:}

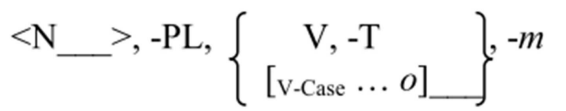

The two features in braces in (26) combine to insert the suffix $-m$ after all $o$-stem nouns in accusative contexts. After all "non-neuter" nouns, $-m$ is a genuine accusative inflection, alternatively realizing the features of $Q$ and $\mathrm{V}\{-\mathrm{PL}, \mathrm{V},-\mathrm{T}\}$ as a suffix on $\mathrm{N}$. On the other hand, on inherently case-marked ("neuter") nouns, this suffix is technically not a case inflection; as it spells out only the feature $P L$.

I next treat the nominative singular suffix $-s$, which declensional accounts generally gloss over. The synchronic regularity - that most non-neuter (not all) nominative singular forms end in -s - is either unmentioned or taken as a vestige of a lost Indo-European regularity. Counter to this traditional lore, absence of final $-s$ is not a "first declension property" and moreover an exceptional variant of $-s$ in the third. Rather, the restriction is phonological; -s fails to occur in nominal singulars only after coronal sonorants or the central vowel a, i.e. after stemfinal $\{a, l, r, n\}$. The proper way to exclude $-s$ in these forms is, as elsewhere in Latin inflection, in terms of phonological features. These four seemingly exceptional final segments are precisely the class of Latin phonemes which developed theories of under-specification have treated as lacking positive specification for Place. Phonetic 
segments are in general specified in terms of Place features such as \pm Front and \pm Peripheral, which indicate an "Articulator" where the top of the vocal tract is constricted (at the lips, teeth, alveolar ridge, palate, velum, etc.). However, a few phonetic/phonological segments lack an Articulator; in particular, central vowels such as $a$ and $\dot{t}$ are unspecified for this property (Goad 1993: Sect. 2.2.2). I notate such sounds as -Place, without implying how the + values should be specified. Thus, the Latin vowels and glides $i, u, e$ and $o$ are +Place (they have an Articulator), while (only) $a$ is Place.

Using similar considerations, Rice and Avery (1991) argue that the so-called "coronal sonorants" $l, n$ and $r$ also function phonologically as if they are unspecified for an Articulator, in particular in languages (such as Latin) that do not have distinctive alveolar and palatal obstruents e.g. $s$ vs. š or ts vs. $\check{c}$. Coronal consonants lacking Place features, like central vowels, are fully characterized by features for the shape of the vocal cavity (the tongue configuration), specifying lateral vs. nasal air passage $(I, n)$ or depressing the acoustic third formant $(r)$. For these authors, these consonants also lack Place specification, unlike labials, dentals, velars, etc.

In terms of PLACE specification then, the lexical entry for Latin nominative singular -5 is as follows.

(27) Latin nominative singular: ${ }^{37}$ $<\mathrm{N}_{---}>,-\mathrm{PL}, \mathrm{V},+\mathrm{T}, \quad \ldots[+ \text { Place }]_{--},-s$

After stems whose final segment is -Place, Latin simply has no nominative singular case inflection, which is an option permitted by the Obligatory Inflection Parameter (22). ${ }^{38}$

37 A few neuter stems with final $r$ appear to irregularly exhibit $-s$ in the nominative singular: aes 'money', corpus 'body', genus 'tribe', jūs 'justice', ōs 'mouth' (with genitives aer-is, corporis, gener-is, jūr-is, ōr-is). But these nouns derive from Indo-European stems that ended in $s$, which later became $z$ and then $r$ between vowels, suggesting that their final $s$ is not the inflection $-s$ (C. Watkins, class lectures 1966-67). If this "rhotacized" $s(s \rightarrow r)$ is a Latin synchronic process that applies only before morpheme boundaries as pointed out by McCarthy (2003), most intervocalic $s$ do not undergo it - then (27) fully accounts for all instances of the true nominative singular suffix $-s$.

${ }^{38}$ The same lack of nominative singular inflection characterizes non-neuter nouns in the not too dissimilar system of Czech case.
We have seen how many parenthesized stem-final consonants are subject to the Lexical Parentheses Convention (14). A parenthesized stem-final segment can also be a post-consonantal vowel. In this situation the vowel surfaces only in nominative singulars, since in other cases this consonant itself is differently specified for \pm Syllabic than the initial vowels of the inflections (whether lexical or epenthetic). Thus lexical representations of various nouns such as coll(i)- 'hill', fin(i)- 'end', $n \bar{v} v(i)$ 'ship', orb(i)- 'circle' give rise to often identical nominative-genitive pairs, though the divisions between stem and suffix are different: colli-s, coll-is; fini-s, fin-is; nāvi-s, nav-is; orbi-s, orb-is. Though these nouns straightforwardly exemplify the Lexical Parentheses Convention, handbooks often list them as "exceptions". ${ }^{39}$

Entry (27) brings out an important difference between lexical specifications and phonological rules. Section 5 has shown that parenthesized final segments of noun stems are used only to enhance CVCV patterning: aetā(t)- 'ancient times,' bo(v)- 'cow', fōn(t)'spring', lapi(d)- 'stone', Iau(d)- 'praise', rātiō(n)- 'reason', requiē(t)- 'rest', virtu(t)'courage', $\operatorname{sermō}(n)$ - 'speech'. If entry (27) were simply a left-hand context in a phonological rule, then the segment preceding parentheses might determine the choice between $-s$ and $-\varnothing$.

However, lexical insertion depends only on lexical representations of adjacent morphemes, so what counts in (27) as the context for choosing an allomorph is the last segment in the noun's lexical entry, i.e. those in parentheses. In a given string, these segments often do not precede the place of $-s$. Thus the following nominative singulars in $-s$ are all due to absent stem-final lexical segments that are -Sonorant and +Place: stem-final $t$ : ars, aetās, fōns, līmes, mēns, requiēs, virtus; stem-final v:bos; and stemfinal $d$ : lapis, laus. At the same time, rātiō

${ }^{39}$ Unsurprisingly, usage fluctuated for some noun stems with identical nominatives and genitives. For instance, the lexical representations nāv(i) 'ship' and ign(i) 'fire' yield ablative singulars nāve and igne, while the lexical stems nāvi and igni yield instead nāvī and ignī. A few truly exceptional contrasts between stems and nominative singulars of course remain, such as iter, itineris 'way', Juppiter, Jovis 'Jupiter'. But the number of true irregularities is far less than the impression given in Latin grammars. 
and sermō lack final $-s$ in the nominative singular because the final segment in their lexical representations is the coronal sonorant $n$, which is -PLACE. ${ }^{40}$

\section{Latin V-assigned case: non-neuter plurals}

${ }^{40}$ A problem remains with the lexical stems puer(o) and agr(o). According to the text, their nominative singulars should be $-s$ rather than $-\varnothing$. If there is no fully phonological account of $-s$ vs. $\varnothing$ in (27), -s should be excluded with Ns like puer(o) by lexically listing them with an optional inherent nominative feature $(+T)$, analogous to the inherent $\mathrm{V}$-marked case features $(\mathrm{V})$ of "neuter" stems.
It remains now only to specify an entry for all the plurals of $V$-assigned cases for all classes of nouns. There is a special allomorph $-\bar{\tau}$ for nominative plural stems ending in an underlying low vowel. The underlying word-final sequences for these plurals are thus the diphthongs $a-\bar{I}$ and $o-\bar{I}$. By the truncation rule (3) the final sequence oi does not surface but is phonetically realized as $-\bar{T}$ : equi 'horses', servī 'slaves'. In contrast, Early Latin ai, later respelled as ae, was apparently pronounced as a long mid vowel: nautae 'sailors', terrae 'lands".

For all other forms, Latin non-neuter plurals have a single allomorph for both nominatives and accusatives. Here is the relevant data:

(28) Latin inflections for V-assigned case on plural Ns:

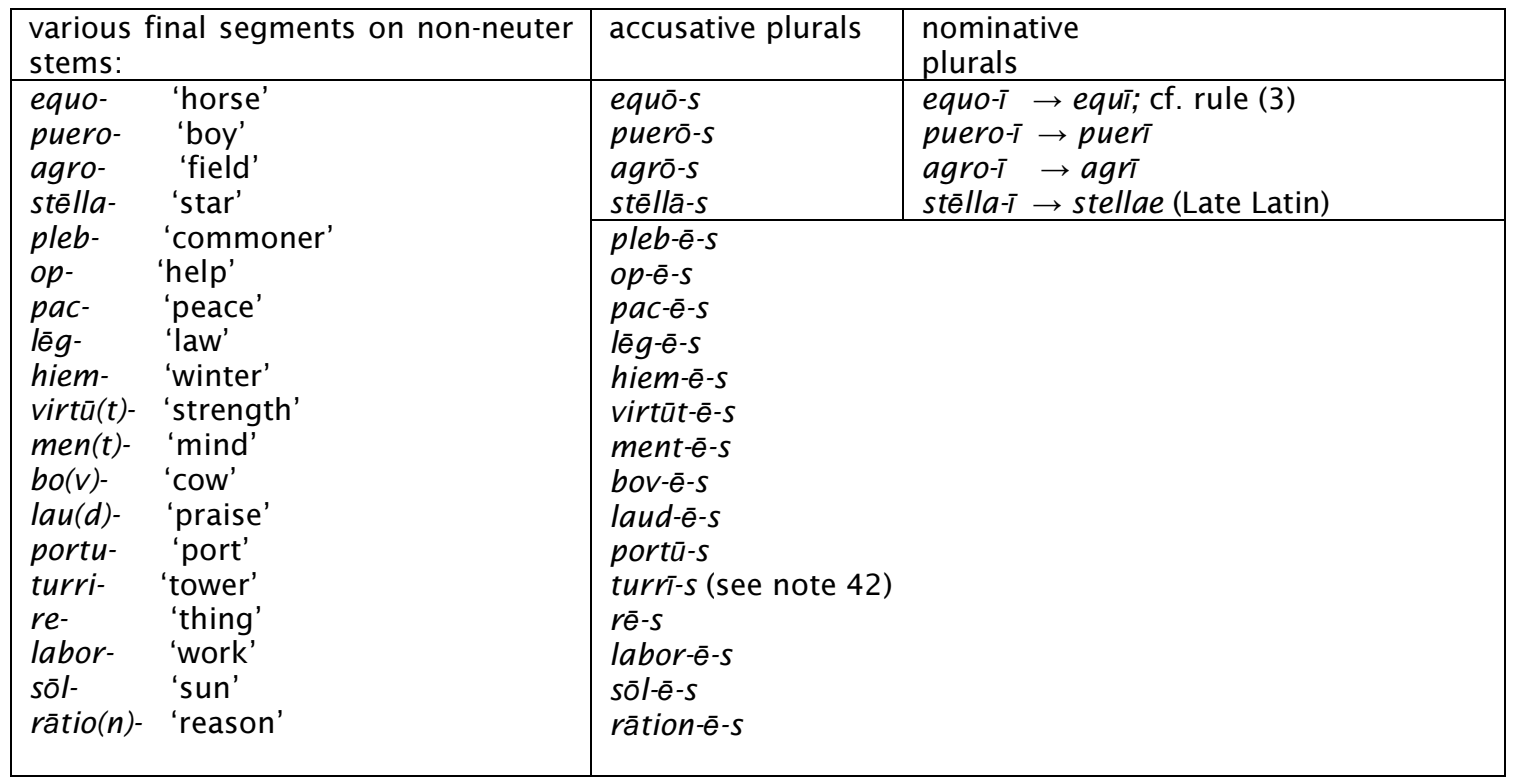

Since the allomorph $-i$ of plurals occurs only in nominatives, its lexical entry alternatively realizes both $\mathrm{V}$ and $\mathrm{T}$ Case features on $\mathrm{Ns}$ after only low vowels $a$ and $o$, the so-called first and second declensions. This is seen in column 3 of Table (28). ${ }^{41}$

\section{(29) Special nominative plurals:}

$$
<\mathrm{N}_{---}>,+\mathrm{PL}, \mathrm{V},+\mathrm{I}, \ldots[\text { [+Low] }]_{---},-\bar{T}
$$

The remaining nominative and accusative plurals of all other Latin nouns are syncretic,

${ }^{41}$ Entry (29) supports Spaelti's (2004) argument that Latin $o$ patterns as a low rather than a mid vowel. which further justifies conflating $T$ and $V$ with a unified case-assigning feature $V .{ }^{42}$ This V-marked inflection consists of "vowel length $+s$ ", i.e. a stem-final vowel lengthens and is followed by $s$. Predictably then, accusative plurals of the $-a\left(1^{\text {st }}\right),-o\left(2^{\text {nd }}\right),-u$ $\left(4^{\text {th }}\right),-e\left(5^{\text {th }}\right)$ and $-i$ declensions, including

${ }^{42}$ As a reviewer notes, the system here does not account for why the nominative and sometimes the accusative plurals of noun stems with final $-i$ irregularly end in -ēs rather than the expected $-\bar{i} s$. If these cases are really distinct and not an artefact of textual survivals, it is the only place where this syncretism in the text doesn't hold. 
here their stem vowels for clarity, are respectively $-\bar{a} s,-\bar{O} s,-s,-\bar{e} s$ and $-\bar{T} s .{ }^{43}$

The entry (30) for this allomorph generates the plural nominatives of all nouns in Table (28) not covered by the more specific (29) as well as all (non-neuter) plural accusatives.

(30) Elsewhere $V$-assigned plurals: $<\mathrm{N}_{---}>,+\mathrm{PL}, \mathrm{V}$, [+Long]-s

This nominative/accusative syncretism extends to stems with final consonants (the " $3^{\text {rd }}$ declension"). A word-final sequence "...[+Consonant]-[+Long]-s" implies that some (long) vowel must intervene between the consonants. Thus this suffix's initial segment [+Long] lengthens not only stemfinal vowels but also epenthetic vowels inserted to realize this feature. The Latin epenthetic vowel is $e$ (cf. the Appendix), so that (30) gives rise to a plural inflection -ês after consonant-final stems. With this understanding of how epenthesis interacts with lexical vowel length, (30) accounts for all the $\mathrm{V}$-assigned plurals in Table (28).

To reflect the fundamental unity of Latin nominatives and accusatives, the two case allomorphs for its $\mathrm{V}$-assigned plurals can be written as one lexical entry:

(31) Generalized V-assigned plural case:

$$
<\mathrm{N} \_>,+\mathrm{PL}, \mathrm{V},\left\{\begin{array}{c}
f \mathrm{~T}, \ldots[+\mathrm{Low}] \_,-\bar{\imath} \\
{[+ \text { Long }]-s}
\end{array}\right\}
$$

${ }^{43}$ The V-assigned case suffix is can be supplanted by $\bar{e} s$, especially in the nominative (Stock, 1971, pp.15-16). The alternation is plausibly part of the Late Latin tendency in final closed syllables to lower long high vowels and raise short mid vowels; cf. note 8 .
Conclusion and compact summary of results

This essay's phonology-based analysis of Latin case inflection is entirely different in nature from ones based on arbitrary declensions and/or any putative autonomous component or level of morphology. All of Latin's "special nominal morphology" has dissolved into linguistically rather prosaic lexical entries that use only independently justified categories of syntax (standard case-assigners) and phonology (standard distinctive features).

There does remain the question of how Latin speakers mentally represented the separate lexical specifications for the dozen bound suffixes; singular and plural suffixes for a single case may be allomorphs, or they may result from separate lexical entries. They possibly learned these specifications separately, but also, given the natural language penchant for cross-classification (which linguists' analyses simply make explicit), they may have constructed a two-dimensional matrix for case and plural values and then as learning proceeded elaborated entries for each case/number combination. Whether or not speakers actually conceptualized case inflection with such a matrix, we can do so here if nothing else as a means of summarizing results.

Such a matrix can dispense with many of the braces in evidence in the separate lexical entries, since the lines in each entry can be taken as mutually exclusive, with the last line being a default for a given case and number combination. I retain the braces simply for clarity and facilitating comparison with the earlier separate statements of lexical entries.

\section{(32) Matrix for all Latin nominal case inflections}

\begin{tabular}{|c|c|c|}
\hline Case features in contexts $\left[_{N} \mathrm{~N}_{--}\right]$ & -PLURAL & + PLURAL \\
\hline $\mathrm{V}$ (nominatives and accusatives): & $\begin{array}{l}+T, \ldots[+ \text { Place }]]_{--},-s \\
-T, \quad-m\end{array}$ & $\left\{\begin{array}{c}+\mathrm{T}, \ldots[+ \text { Low }]_{--,},-\bar{T} \\
{[+ \text { Long }-s}\end{array}\right.$ \\
\hline But if $\mathrm{N}$ has inherent lexical V-case: & $\ldots o_{---},-m$ & $-a$ \\
\hline Q (genitives): & $\left\{\begin{array}{c}\ldots[-\mathrm{High}]_{---},-\bar{\top} \\
-(i) s\end{array}\right.$ & (r)um \\
\hline P (datives and ablatives): & $\left\{\begin{array}{c}+ \text { GOAL }, \ldots[- \text { Round }]_{--},-\bar{I} \\
{[+ \text { Syllabic }]}\end{array}\right.$ & $\left\{\begin{array}{c}\ldots\left[+ \text { Low }_{---},-\bar{I} s\right. \\
\text {-ibus }\end{array}\right.$ \\
\hline
\end{tabular}

Observe that this summary table contains no redundancies or repetitions, unlike the tedious declensional tables of traditional
Latin pedagogy. Each phonological and syntactic conditioning factor is stated but once, and each combination of Case and 
Number features has at most two allomorphs. The entire system fits on seven lines! We can imagine that Rome's children, after acquiring these case and number paradigms, had a lot of mental space left over to learn many other things about their language - unlike the beleaguered pupils of school Latin forced to learn declensions in the many centuries since.

Indeed, this essay has argued that the venerable and purely morphological classifications called Latin declensional classes are pure illusions, with no role in either the Phonology or the Syntax/Semantics of generative models. This conclusion fits into a wider research perspective, which is to show that, beyond syntax and phonology, natural language contains no special "Morphological Component" (Aronoff 1994), also known as "Morphological Structure" or Autonomous Morphology (1). In particular, this essay supports the claim that traditionally conceived "paradigms" have no status in linguistic theory; see also Bobaljik (2008).

Of course, detailed investigation of one language's bound morphology does not in itself show so much about that of unrelated languages. But partly, the issue is one of burden of proof. Since any student of language structure who might read this essay takes for granted that syntax and phonology both have (largely different) categories and combinatorial principles, the question is, are there any further linguistic categories, i.e. of morphology, that are independently justified? The long tradition of Latin grammar is widely assumed to provide support for an affirmative answer. If this support is removed, then each weaker and less firmly supported claim for Autonomous Morphology must be evaluated on its own merits, as violations of scientific parsimony but perhaps necessary for adequate linguistic descriptions. In my view, as such claims are successively scrutinized, they will all collapse. ${ }^{44}$

44 Another persistently proposed purely morphological construct is "templates" for wordinternal combinations of morphemes, such as the surface constraints of Perlmutter (1971). In fact, proponents of templates often concede that they are not observationally adequate. Thus, Perlmutter's constraint for French clitics fails to exclude sequences such as *il me leur présente 'he-me-to them-introduces', "nous $y$ en achetons 'we there some buy'.

\section{Appendix. A note on Latin Epenthesis 45} Several points in the exposition have referred to vowel epenthesis in Latin, i.e. the insertion of a vowel in certain consonantal environments. More generally, epenthesis is a process of inserting under certain conditions segments that a language treats as "neutral" or "phonetically economic." In particular, epenthesis is insertion of a segment of minimal phonetic effort with the effect of enhancing consonant-vowel (CVCV) alternation.

A vowel of least effort is plausibly the one in the centre of a language's "vowel space," sometimes referred to as a "vowel triangle." Moreover, since Latin $e$ acts phonologically as a mid vowel, while $o$ acts as a low vowel (Spaelti, 2004), its sole mid-vowel is $e .^{46}$ It is therefore not surprising that several empirical patterns of Latin phonology and morphology support Spaelti's claim (33), which this essay has also assumed:

(33) Latin vowel epenthesis. Latin's epenthetic vowel is $e$, its only mid vowel.

The question that arises is of course, what triggers (vowel) epenthesis in a given language? The central factors seem to be twofold but both are phonological:

(34) Condition for epenthesis. Vowel epenthesis is triggered when phonology, via either lexical entries or a phonological derivation, gives rise to a post-consonantal [+Syllabic] segment unspecified for vowel quality.

The summarizing Table (32) contains two allomorphs whose lexical entries include (sometimes post-consonantal) vowel segments unspecified for quality: ablative singulars consist of a single [+Syllabic] segment (7) and V-marked plurals (30) can include a [+Long] segment. As (34) then predicts, stem-final consonants on $\mathrm{Ns}$ give rise to epenthetic ĕ and $\bar{e}$ respectively.

${ }^{45}$ The phonological insertion of a vowel otherwise unspecified for its quality is standardly called epenthesis. I leave the issue of how best to lexically represent this vowel length condition to phonological theorists who are familiar with similar conditions in other languages.

${ }^{46}$ Latin has two high and two low vowels, while $e$ has intermediate height. English schwa and French rounded schwa are other examples of least effort vowels in centers of vowel spaces. 
A third Latin lexical entry that underspecifies a syllabic segment is the infinitive suffix, whose phonological form is uniformly "[+Syllabic]-re", or perhaps "[+Syllabic]- $r$ [+Syllabic]". Verb stems in three classes or "conjugations" end in unrounded vowels, - $a$ (lauda- 'praise'), -e (mone- 'warn') and -i (audi- 'hear'), while those in a fourth class end in consonants (mitt- 'send'). Exactly as in ablative singular nouns, an initial inflectional segment [+Syllabic]... then either lengthens a stem-final vowel ( $\rightarrow$ laudāre, monēre, audīre) or after a consonant leads to epenthetic ĕ ( $\rightarrow$ mittere). ${ }^{47}$

Some instances of vowel epenthesis are due to Latin phonology, independently of lexical entries. In general, Latin's epenthetic segment $e$ appears after a consonant before a final sonorant consonant $(r, m, n, l)$. \# informally represents word boundary. ${ }^{48}$

${ }^{47}$ The length of an epenthetic vowel unspecified for length is short.

${ }^{48}+$ Son $=$ +Sonorant and +Cons $=$ +Consonantal. Rule (35) is proposed as an example and is certainly insufficiently general. For example, as a reviewer suggests, the lack of final $\mathrm{Cm}$ in Latin is due to the language's general phonotactics rather than to a specific rule. That is, rule (35) is meant to be explicit, but doesn't aim for full generality. This Appendix isn't intended as a full account of Latin epenthesis.
(35) Final syllable epenthesis: $\varnothing$ [+Syllabic] /[+Cons]_-_[+Son, +Cons] \#

By virtue of (35), or some generalization that subsumes it, Latin excludes a word final combination consonant $+m$. So if one adds the accusative singular inflection $-m$ to noun stems with final consonants (pleb-, urb-, laud-, lēg-, op-, aetat-, pac-, class-, hiem-, rātion-, patr-, labor-, sōl-, etc.), then epenthesis, i.e. (33) and (35) taken together, correctly yields the accusative singulars plebem, urbem, laudem, lēgem, opem, aetatem, pacem, classem, hiemem, rātionem, patrem, laborem, sōlem, etc.

Similarly, many lexical stems of Latin nouns and adjectives end in consonant $+r$, as evidenced by the fact that this sequence appears before all overt case suffixes: agr'field', fratr- 'brother', libr- 'book', patr'father', acr- 'sharp', pulchr- 'beautiful'. Because (35) also excludes a word-final combination of consonant $+r$ and at the same time (32) provides no nominative singular suffix for stems ending in $r$, an epenthetic vowel is again required, and as expected it is again $e$ : ager, frater, liber, pater, acer, pulcher.

\section{References}

ARONOFF, M., 1994. Morphology by itself: Stems and inflectional classes. Cambridge, MA: MIT Press.

BABBY, L., 1980. The syntax of surface case marking. Cornell Working Papers in Linguistics 1, pp. 1-32.

BAKER, M., 1985. The Mirror Principle and morphosyntactic explanation. Linguistic Inquiry, vol.16, pp. 373-416.

BALDI, P. and CUZZOLIN, P., 2009. New perspectives on historical latin syntax 1. Berlin:

Mouton de Gruyter.

BERMUDEZ-OTERO, R., 2007. Morphological structure and phonological domains in Spanish denominal derivation. In: F. Martínez-Gil and S. Colina, eds. Optimality-theoretic studies in Spanish phonology. Amsterdam: John Benjamins, pp. 278-311.

BOBALJIK, J., 2008. Paradigms, optimal and otherwise: A case for skepticism. In: A. Bachrach and A. Nevins, eds. Inflectional identity. Oxford: Oxford Univ. Press, pp. 29-54.

CHOMSKY, N., 1981. Lectures on governement and binding. Berlin: Mouton de Gruyter. CHOMSKY, N. and HALLE, M., 1968. The sound pattern of English. New York: Harper and Row.

CSER, A. (to appear). The nature of phonological conditioning in Latin inflectional morphology. Acta Linguistica Hungarica.

EMONDS, J., 1985. A unified theory of syntactic categories. Berlin: Mouton de Gruyter. EMONDS, J., 1987. The invisible category principle. Linguistic Inquiry, vol.18, pp. 613-631. EMONDS, J., 2000. Lexicon and grammar: The English syntacticon. Berlin: Mouton de Gruyter.

EMONDS, J., 2009. De declinationibus disputandum est. In : P. Karlík, ed. Development of language through the lens of formal linguistics. Munich: Lincom Europe, pp. 63-85. 
EMONDS, J., 2010. Case theory revisited: Nominative and accusative super case. In: A. Bičan, J. Klaška, P. Macurová a J. Zmrsliková, eds. Karlík a továrna na lingvistiku. Brno : Masaryk University Press, pp. 98-124.

EMONDS, J., 2012. Blackjack! 21 arguments that Agreeing Adjectives are Derived Nominals. In: E. Torrego, ed. Of grammar, words and verses. In honor of Carlos Piera. John Benjamins Publishing, Amsterdam, pp. 171-200.

EMONDS, J. and SPAELTI, P., 2005. Fully distributing morphology: The phonology and syntax of Latin case inflections. In: Theoretical and Applied Linguistics at Kobe Shoin 8. Kobe Shoin: Kobe Shoin, pp. 1-20.

EMONDS, J. and OSTLER, R., 2006. Thirty years of double object debates. In: M. Everaert and $\mathrm{H}$. van Riemsdijk, eds. The Blackwell companion to syntax. London: Blackwell Publishing. GOAD, H., 1993. On the configuration of height features. University of Southern California doctoral dissertation.

GRIMSHAW, J., 1990. Argument structure. Cambridge Mass: MIT Press.

HALLE, M. and MARANTZ, A., 1993. Distributed morphology and the pieces of inflection. In: K. Hale and S J. Keyser, eds. The view from building 20: Essays in linguistics in honor of Sylvain Bromberger. Cambridge MA: MIT Press, pp. 111-176.

HALLE, M. and NEVINS, A., 2009. Rule application in phonology. In: Ch. Cairns and E. Raimy, eds. Representation and architecture in phonological theory. Cambridge MA: MIT Press, pp. 355-382.

HENLE, R., 1945. Latin grammar. Revised Edition. Chicago: Loyola University Press. MCCARTHY, J., 2003. Comparative markedness. Theoretical Linguistics, vol. 29, pp. 1-51. LARSON, R., 1985. Bare NP adverbials. Linguistic Analysis, vol. 18, pp. 595-621. PERLMUTTER, D., 1971. Deep and surface constraints in syntax. New York: Holt, Rinehart and Winston.

RITTER, E., 1993. Where's gender? Linguistic Inquiry, vol. 24, pp. 795-803.

RICE, K. and Avery, P., 1991. On the relationship between laterality and coronality. In: C. Paradis and J.-F. Prunet, eds. Phonetics and phonology 2: The special status of coronals. San Diego: Academic Press, pp. 101-124.

SAPIR, E,. 1921. Language: An introduction to the study of speech. New York: Harcourt Brace. SPAELTI, P., 2004. Some phonological and morphological patterns in the Latin noun declension system. Theoretical and Applied Linguistics at Kobe Shoin 7. Kobe Shoin: Kobe Shoin, pp. 131-137.

STOCK, L., 1971. Langenscheidts kurzgrammatik latein. Berlin: Langenscheidt. VESELOVSKA, L., 2001. Agreement patterns of Czech group nouns and quantifiers. In N. Corver and H. van Riemsdijk, eds. Semi-lexical categories., Berlin: Mouton de Gruyter. WHITNEY, W.D., 1889. Sanskrit grammar. Cambridge, MA: Harvard University Press.

\author{
Author's address and contact details \\ Joseph Embley Emonds \\ Katedra anglistiky a amerikanistiky \\ Univerzita Palackého v Olomouci \\ Kř́žkovského 10 \\ Olomouc 77180 \\ Czech Republic \\ Phone:+420 585633103 \\ E-mail: joseph.emonds@upol.cz
}

